\title{
NATURE
}

\section{Once More into the Breach}

THE opening this week of negotiations between Britain and three Scandinavian countries with the European Economic Community is an important but inevitable stage in the economic history of Europe. If the negotiations should break down a third time, it will be necessary to open them again a few years from now. For in spite of appearances, mostly in the textbooks, there is no way of avoiding some kind of agreement between mainland Europe and the outlying parts to the north and west. Not merely are there mutual benefits to be won by a closer coordination of economic policy. In the long run, more importantly, there are also great political benefits to be won by something in between the loose arrangements for coordination, which at present exist through institutions like the Organisation for Economic Cooperation and Development, the Western European Union and the Council for Europe, and fully fledged political integration of Western Europe, which is bound to be a long way off. So the interest in the talks now begun will lie not merely in the prospect which they provide of a rapid answer to the British and Scandinavian request for membership, but also in the signs that will emerge of the extent to which historically necessary tendencies are under way.

In circumstances like these, science and technology have important contributions to make even if they are, almost by definition, peripheral. To begin with, it is important that the technical people engaged in the talks at Brussels should not encourage or seem to encourage some of the more unreal schemes which have been suggested for using technical projects as foci for collaboration.

In the past decade, there have been plenty of examples of how European countries, particularly Britain and France, have put the cart before the horse in ways like these. The whole concept of ELDO, for example, derives from Mr Peter Thorneycroft's hope that the British Blue Streak rocket Launcher, no longer needed as a military weapon, could be used to further British-European designs in the early sixties. The result, predicted at the time, has not been sweetness and light but rather the opposite, an impediment to good relations. Much the same is true of the Concordethe tangible illustrations which there have been of how French and British technologists can work harmoniously together round a drawing board have been more than offset by the bickering between governments, and between governments and their electorates, about the cost and the use to be made of Concorde. The most immediate moral is that no amount of goodwill for international collaboration should ever again permit one government to sign an agreement containing no provisions for bringing the project to an end. More distantly it should be plainly understood that there are limits to the extent to which technical expertise and a willingness to collaborate can allow two powerful nations to fly in the face of what may be the realities of the market for supersonic transport. In short, the first task for technology is to assure the politicians that the conjuror's hat is empty of rabbits. One of the dangers in Mr Harold Wilson's talk, when Prime Minister, of what he called the European Technological Community is that it smacked too much of letting the wish be the father of the thought.

This does not imply that science and technology have nothing to contribute towards European unity. First, there are important opportunities to be seized in the specialization of European industry. The time must come when British industry is willing to buy its chemicals (or some of them) from Italy, when German companies are prepared to buy computers (or even sometimes machine tools) from Britain and when French industry is willing to shop in Germany for electrical machinery or process plant. The difficulties of setting up thoroughly European companies are serious, but probably not as serious as they sometimes seem as impediments to this kind of specialization. The original Treaty of Rome, now sometimes honoured in the breach, was intended to bring about precisely such a state of affairs. Instead of spreading advanced technology, computers, chemicals and the like, uniformly over the face of Europe, the intention was to let people move freely where their skills could be best used. One of the regrettable features of the development of the EEC in the past few years has been its avoidance of decision.

The second important task which scientists and technologists can perform is to remind politicians that nothing like a coherent technology can grow up in Europe until the whole resources of European education systems, schools and universities, are coherently used for the development of technical skills. This implies freedom of movement for academics and professional people, the freedom of students to apply for entry to any university where they think some special benefit is to be obtained, and the freedom of researchers to look for financial support wherever this may be most helpfully supplied. In the long run, such arrangements are inseparable from anything deserving to be called a community. Nevertheless, they are not nearly such hot potatoes as proposals for common European defence, now likely also to be revived. They should be a valuable touchstone of good intentions in the weeks ahead. 